\title{
Peripécias na alcova de Sade: a mulher em La Philosophie dans le boudoir
} Incidents in Sade's alcove: The figure of woman in La Philosophie dans le boudoir

\author{
Edson Santos Silva ${ }^{1}$
}

WALLAS JEFFERSON DE LIMA ${ }^{2}$

Resumo: 0 artigo analisa a maneira com que as personagens femininas aparecem no livro A Filosofia na alcova do Marquês de Sade. Destaca temas recorrentes do autor como espaço, vida privada, liberdade relacionando-os com a discussão sobre o papel da mulher durante o século XVIII na França. Tal opção temático-espacial analisa, portanto, pontos poucos estudados em profundidade e que durante muito tempo se constituíram apenas em adendos nos estudos do contexto pós-revolucionário francês. A discussão se insere nos marcos da intercessão teórica entre História e Literatura, tendo como referencial os trabalhos de Georges Bataille, Michele Perrot, Eliane Robert Moraes e Lynn Hunt.

Palavras-chaves: Mulher; história; literatura; França; século xvIII.

\begin{abstract}
The article analyzes the way the female characters appear in the book A Filosofia na alcova of Marquis de Sade. It highlights the author's recurrent themes, such as space, private life and freedom, relating them to the discussion about the role of women during the eighteenth century in France. Such a thematic-spatial option analyzes, therefore, points that were not thoroughly studied and that, for a long time, were only considered in addendums within the studies about the French post-revolutionary context. The discussion is part of the theoretical intersection between History and Literature, using as reference the works of Georges Bataille, Michele Perrot, Eliane Robert Moraes and Lynn Hunt.
\end{abstract}

Keywords: Woman; story; literature; France; eighteenth century.

${ }^{1}$ Universidade Estadual do Centro-Oeste.

${ }^{2}$ Universidade Federal do Paraná. 
O objetivo deste artigo é demonstrar como o sexo feminino aparece especificamente em $A$ Filosofia na alcova, livro de autoria de Donatien Alphonse François de Sade, mais conhecido apenas pelo epíteto «Marquês de Sade» (1740-1814). A escolha por este autor não é aleatória como talvez possa parecer. Sade é filho do século XVIII, considerado um período histórico ainda mal elucidado pelos próprios historiadores. Foi esse século que viu nascer em seu meio um novo papel do Estado, o desenvolvimento do fenômeno anticlerical e os progressos no acesso à escrita e à leitura. Foi também o século da Revolução Francesa, ruptura importante entre o Antigo Regime e a nova sociedade liberal.

Como explicar que, em meio a um período caracterizado pelo uso da extrema violência, durante o qual até mesmo reis passavam pelo crivo dos tribunais da guilhotina, o homem tenha se preocupado em enriquecer o domínio das Artes? Essa questão já foi proposta por Georges Bataille, reconhecendo que, à primeira vista, o período pós-Revolução assinala um tempo «pobre» da Literatura na França (2015: 100). Todavia, essa aparente contradição nega em si mesma uma verdade pouco estudada: houve sim uma rica produção cultural, intelectual e literária no século XVIII, mas que, perante a opinião pública, possuía má reputação³.

\footnotetext{
${ }^{3}$ Eric Hobsbawm também considerava o século XVIII como período rico em produções artísticas. Destacou que os artistas se envolviam com assuntos de interesse público e que a Litera-
}

Sade se insere exatamente nesse período literário de má fama, atestando, com efeito, a existência de livres pensadores que utilizavam o grotesco para criticar a sociedade e que foram responsáveis por desenvolverem a transgressão na cultura literária da época. Abordavam aspectos que a sociedade queria silenciar. É preciso lembrar que aos poucos o estado buscava laicizar-se e que isto foi um processo lento. A religião ainda tinha muita relevância na vida dos homens do Setecentos.

Os resultados que se apresentam são a título de ensaio; por não serem homogêneos, baseiam-se em uma determinada amostragem de textos advindos da obra em questão. Se oferecem mais perguntas do que respostas, é porque constituem uma riqueza analítica ainda a ser melhor estudada. Os autores entendem, porém, que respostas parcelares são uma base segura para um balanço certamente mais híbrido.

\section{A mulher e o contexto revolucionário francês}

Vem do historiador Philipe Ariès a ideia de que o ingresso do Ocidente na cultura escrita constitui uma das principais evoluções do mundo moderno. Para ele, uma série de fatores deveriam ser considerados para uma

tura dessa época ficou marcada por prosas caracterizadas por análises sutis de relações pessoais e de exaltação sexual. Em suas palavras, «a sociedade da França pós-revolucionária era burguesa em sua estrutura e em seus valores» (2008: 257). 
análise mais acurada do tema: não se trata de estudar apenas a circulação da palavra escrita, mas, acima de tudo, de compreender como a difusão da leitura e os progressos da alfabetização ajudaram a constituir o desenvolvimento e a produção do mundo das letras na Europa Ocidental. Infelizmente, tal evolução civilizacional não foi capaz de eliminar práticas um tanto arcaicas. Uma delas diz respeito ao acesso à escrita. Nesse quesito, é preciso reconhecer que o papel, a pena e a tinta estiveram, quase sempre, sob a posse do macho. Prova disso é o número historicamente ínfimo de obras literárias escritas por mulheres. Esta era uma realidade ainda em voga no século XVIII francês. Mesmo o Humanismo, que fez da instrução o principal meio da educação, não foi capaz de igualar homem e mulher no que tange à entrada no mundo da escrita. Durante boa parte do Renascimento europeu, somente parcela da elite feminina tinha relativo acesso à escrita.

Tal constatação demonstra que elas não escreviam a respeito delas. Reduzidas ao silêncio, as mulheres foram ignoradas pelos escritores em vários momentos da História. Omitiu-se, assim, o que elas pensavam, sentiam e viviam. Admitir esse caráter excludente implica aceitar que imagens literárias relacionadas ao feminino geralmente estão atravessadas pelo olhar masculino. Todavia, não se deve tomar esta diferença como medida exata de uma desigual capacidade de leitura. Em outras pa- lavras, se, por um lado, as mulheres quase não escreviam, por outro, elas liam. E liam muito.

A França do século XVIII em especial estava se transformando profundamente. Algumas muIheres, na ampla ebulição causada pela Revolução Francesa, passaram a ter maior acesso à escrita, como demonstram os casos de Louise Labé, Madame de La Fayette e Germaine de Staël. Os próprios personagens criados pelo Marquês de Sade parecem reforçar tal perspectiva. Tome-se o caso de Àgnes, esposa de Arnolphe, em L'école de femmes, e constatar-se-á que em toda revolução há uma contrarrevolução. $O$ marido de Àgnes se desesperava com o simples fato de sua esposa saber escrever, e lhe aconselhava a aprender aquilo que realmente interessava em um contrato marital: ser obediente e fiel ao esposo ${ }^{4}$. É notável que Arnolphe, representante dos clássicos amantes apaixonados da comédia italiana e da Farse Françoise do século xVIII, tenha aproveitado a discussão acerca da leitura para abordar temas de moralidade. No fundo, isso significava que, para ele, Agnès precisava repetir as «Máximas do Casamento» (adágios e ditados populares) e se limitar a ficar sob sua tutela. Liberdade feminina, portanto, é o que está em voga aqui. Esta presunção em

\footnotetext{
${ }^{4}$ «O casamento, Agnès, não é uma pilhéria / Do estatuto de esposa a obrigação é séria / $E$ esta honra a que te elevo em nada se destina / A que andes na folia e sejas libertina / Só para a dependência existe o vosso sexo / Da barba onipotente é pálido reflexo» (Molière, 2011).
} 
«dominar» a fêmea se relaciona com o tema-clichê da infidelidade feminina que, desde a Idade Média, inundava as peças teatrais da Europa renascentista.

Como parênteses, destaque-se que a ideia de que as mulheres também deveriam ter direito à leitura também gerou controvérsia em Portugal. Mesmo no alvorecer do século XIX, esse país ainda possuía taxas bastante elevadas de iletrados. 0 mesmo não se podia dizer dos países protestantes do Norte, que pareciam hipervalorizar o aspecto educacional para que todos pudessem ter acesso à leitura da Bíblia. Embora uma série de razões condicionassem as diferenças entre Portugal e outros países, muitos viram no «catolicismo ortodoxo» um fator de peso para explicar as desproporções no acesso à leitura, reforçando a tese do mal do Seiscentismo Ibérico. Todavia, em se tratando de teses polêmicas, é sempre relevante relembrar o que afirma o historiador Jacques Le Goff: «Nem legenda rosa, nem legenda negra» (1991: 19-45). Para o caso aqui analisado, parece que tal equilíbrio encontra-se em João Luís Lisboa e lago Reis Miranda, que lembram que a escrita não era um ato necessário ao dia a dia da maior parte dos portugueses até o século xvIII (2010: 334-394). É fato que algumas vozes se levantaram ao longo da história contra essa forma de exclusão. É o caso de Luís António Verney, teólogo iluminista português, que defendia a educação formal para todos, independentemente do sexo biológico. Em se tratando das «casadas» e «donzelas» foi categórico: «Persuado-me que a maior parte dos homens casados que não fazem gosto em conversar com suas mulheres, e vão a outras partes procurar divertimentos pouco inocentes, é porque as acham tolas no trato» (1953: 126). Embora enviesado por um olhar superficialmente misógino, a frase chega com força performativa aos ouvidos atuais. Há de se questionar se não estaria insinuando que a leitura ajudasse a quebrar a monotonia do casamento.

Polêmicas à parte, o caso de Portugal espelhava o que ocorria em outros países europeus. A diferenciação no acesso à escrita e à leitura, portanto, parecem ter determinado enormes variações da imagem feminina nas obras literárias em boa parte do Ocidente cristão. Nesse contexto, o que importa destacar é que não eram elas próprias que construíam essa imagem, o que impossibilitava a criação de novas formas de se ver, sentir e analisar o ser feminino. Por que são tão importantes essas ressalvas? Talvez, para mostrar que dominar a escrita é, também, fabricá-la. Além disso, elas evidenciam que a Literatura, enquanto produto cultural, pode contribuir e reforçar a noção machista de «inferioridade» da mulher. Se assim o for, pode ilusoriamente passar a impressão de que há determinadas características atribuídas somente ao sexo feminino ${ }^{5}$.

\footnotetext{
${ }^{5}$ É verdade que isso não surge no Setecentos. A literatura francesa, já no século XVI, inculcava a ideia de que a mulher, por ter útero, reage de maneira diferente às investidas do
} 
Escrever a história da relação da mulher no mundo literário, portanto, significa escrever também a história de um estereótipo.

Ao longo dos últimos anos, os historiadores, a exemplo dos estudiosos da Literatura, têm valorizado a mulher. 0 estudo do sexo feminino abarca em torno de si muitos outros assuntos, como a vida privada, o cotidiano, o amor e tudo que se esconde atrás daquilo que o próprio pudor sempre foi tão renitente em revelar, ou seja, a sexualidade. Apesar disso, Michele Perrot alerta acerca da dificuldade de se escrever essa história: a presença feminina, afirma, «é frequentemente apagada, seus vestígios, desfeitos, seus arquivos, destruídos» (2008: 21). Por estarem excluídas dos papéis públicos, as mulheres são encontradas na Literatura prioritariamente no cenário doméstico: a casa que constitui o seu palco e que se relaciona a seu papel de esposa ou mãe, em que sua ocupação é vista frequentemente como atividade devocional; afinal, é a mulher quem alimenta, fia, planta, cria, cuida do doente e, em alguns casos, assiste o enfermo diante da iminência da morte. A literatura francesa também expressa o espaço além-casa: as mulheres são encontradas em lavadouros, fontes, fornos, pátios, jardins e moinhos; nesses espaços, ficam

amor. Seus órgãos tinham o poder de abalar o equilíbrio do ser. Rabelais escreveu acerca das mulheres: «[A] natureza colocou-lhes dentro do corpo, em local secreto e intestino, um animal, um membro, o qual não existe nos homens» (Ranum, 2009: 243). ali a conversar, a fofocar, a brigar. Basta ler Bergerac, Stendhal, Marivaux e Chérnier para ficar com alguns exemplos.

Curiosamente, o contexto revolucionário francês criou uma série de oportunidades para transformar em ato público aquilo que, em tese, deveria restringir-se ao espaço privado. Ao longo da sua obra, Sade recorre a uma gama de temas que incomodavam seus contemporâneos. Com ironia, transpõe as barreiras estabelecidas pela religião afrontando de maneira direta o teísmo. Embora o excesso sadiano fosse atacado por seus opositores, é evidente que seus escritos eram, ao mesmo tempo, vorazmente lidos. Como explicar essa relação de amor e ódio? A resposta passa por uma análise mais acurada da figura do leitor. De uma hora para outra, ele foi transformado em voyer. A religiosa infiel, a aristocrata de ardores insaciáveis e a mulher do povo violenta ajudaram a fornecer um repertório de intrigas picantes de nobres devassos e libertinos que pouco se interessam pela moralidade cristã.

Do romance em primeira pessoa ao romance epistolar, cabe acrescentar a difusão do romance pornográfico, que se tornou parte importante da produção literária da segunda metade do século XVIII'. Para defini-la, seus

\footnotetext{
${ }^{6}$ Enumerar os romances de âmbito íntimo poderia levar a se indicar tendências. Exemplos dessa literatura não faltam: Histoire de Dom Bougre, portier des chartreux, écrite par lui-même (1718), de Gervaise de La Touche, Thérèse philosophe (1748), do marquês d’Argens, Erotika Biblion (1783), de Mirabeau, An-
} 
contemporâneos usarão termos como «obsceno», «pornográfico», confundindo, em geral, «galante», «erótico» e «libertino» (Goulemot, 2009: 359-396). É, portanto, extremamente delicada a análise de obras desse período, uma vez que exige do leitor cautela e uma solicitude vigilante em relação a cada texto. Ainda assim, é fato que o século xvIII estava saturado de obras eróticas, apesar de ter havido, paralelo a esse fenômeno, a «explosão sentimental», inaugurada pela Nova Heloísa (1761), de Rousseau, da qual Sade se tornará um dos seus principais críticos (Borges, 2015: 209).

As obras de Sade, é bom lembrar, foram jogadas numa espécie de limbo por muitos anos. Considerada perniciosa, perigosa e nociva, os escritos sadianos foram lançados na periferia da Literatura. Apresentavam-se, aos olhos dos seus julgadores, como transgressões sistemáticas das interdições que pesavam sobre o homem «civilizado», como bem lembrou Janne Gallop (2013: 187-202). Nesse sentido, será preciso esperar muitos anos para que o reconhecimento e o valor literário das obras de Sade sejam reconhecidos pelos seus pares: para Bataille, foram Jean Paulhan, Pierre Klossowski, Maurice Blanchot, Baudelaire, Appolinaire, Breton e Éluard que alçaram a escrita sadiana à figura de proa na contemporanei-

ti-Justine (1793), de Rétif de la Bretonne, Les bijoux indiscrets (1748), de Diderot, Le temple de Cnide (1725), de Montesquieu, Cândide (1759). dade, lançando-a na maré da visibilidade literária. Ainda assim,

Não se pode reduzir o romance de Sade ao pornográfico ou ao obsceno. Ele excede essas categorias. Evidentemente, não pode confundir-se com a produção erótica do século. As próprias interdições que pesam sobre ele assinalam a diferença. Podemos nos perguntar se não se devem à exibição orgânica que apresenta. Sade prolonga o discurso sexual até o intolerável do orgânico e do visceral. Todo o discurso do prazer no paroxismo da escritura de Sade expõe o interno anatômico. Sem dúvida, esta era uma das proibições intransponíveis. (Goulemot, 2009: 394)

As letras talvez ajudem a explicar essa ocultação. Em Sade, o vocabulário é adequado às situações: os personagens constantemente se insultam («barba de cornudo», «filha de uma puta», «cadela», «putinha»); a denominação grosseira das partes genitais ${ }^{7}$, o recurso ao vômito, à urina, às fezes e os detalhes macabros colocam Sade à margem das práticas literárias predominantes na França daquele período. Sua obra é uma caricatura (talvez nostálgica) dos paraísos perdidos, pois é ali que o burguês é representado de maneira nua e

\footnotetext{
7 Sade (2015) não economiza em palavras para se referir às partes sexuais: a vagina é chamada de «antro», «lingueta» ou «templo de Vênus» (32), ao pênis dá-se o nome de «Cetro de Vênus», «Membro» (28-29) ou «pau» (36), o ânus é comparado a uma rosa (27) e a um altar (31), mas também é denominado de «templo misterioso» (29), «traseiro» (30) ou «cu divino» (31). Em vez de seios, Sade prefere as palavras «Tetas», «Globos de carne» ou «Montes de Vênus» (28).
} 
crua. Burguês que sofria os solavancos trazidos pela Revolução.

\section{Sade, a mulher e o boudoir:}

\section{uma interpretação}

Atentem-se primeiramente às datas: última década do século XVIII. A conjuntura histórica ainda estava em ebulição: desintegração do Estado absolutista, nascimento da noção de Direitos Humanos, valorização do papel do cidadão na política. 0 modo de ser dessas situações suscitava naquele período muitas reflexões. Paralelo a tais fenômenos, assistia-se à emergência de novas formas romanescas: de Duclos passando por Prévost, Crébillon e Madame de Lafayette, as formas de romance (galante, realista, epistolar, libertino, etc.) se multiplicaram no século XVIII. Nesse ponto, mereceria ser discutida uma questão central para se entender o desenvolvimento dessas obras: até que ponto a Revolução Francesa (17891799) não favoreceu escritas marginalizadas? A questão não é, desde logo, muito prolixa nos estudos históricos, excetuando-se as discussões evocadas por Lynn Hunt (2012) e Robert Darnton (1987).

Fato é que a publicação de A Filosofia na alcova, pelos idos de 1795 , evidencia que um seleto público se sentia relativamente atraído pela literatura libertina. Trata-se de um dos mais ambiciosos e impactantes livros de sua época. É verdade que, por ter servido como espécie de «contranarrativa», escamoteava o que de fato acontecia nas violentas e tumultuadas vidas que as mulheres levavam. Temas como adultério, violência, abandono e abuso eram frequentes nos meios culturais, como bem demonstrou Eric Hobsbawm, em seu clássico A era do capital. Era, em suma, um reflexo do cotidiano, como o indica esse historiador.

Ainda assim, A Filosofia na alcova possui valor incomensurável. Sade teve sua existência atravessada por um momento conturbado, caracterizado pela transição. Por esta razão, o que ele escrevia surgia como um universo dotado de especificidades que se contrapunham à tradição. Forças conservadoras ainda tinham poder e influência política, fato que ajuda a explicar por que o autor de Justine foi preso diversas vezes ${ }^{8}$. Talvez fosse visto como uma criatura maliciosa, desprovida da capacidade de avaliar o sentido do termo «liberdade», um dos lemas da Revolução. Daí que o Direito formulasse regras claras para aplicá-las ao Terceiro Estado. 0 povo tinha liberdade, sim, mas era dosada com a noção de limite. Nem tudo era permitido. O problema é que, em Sade, os extremos constituem a tônica de suas ideias. Nada deveria frear o homem. E isso ainda mais em se tratando de seus instintos mais animalescos.

\footnotetext{
${ }^{8}$ Para ser mais preciso, o marquês de Sade viveu, em plena era do Terror, na Prisão de Madelonnettes, dois anos antes d'A Filosofia na alcova ser publicado. Todavia, entre 1778 e 1790 ele passou onze anos encarcerado na prisão de Vincennes e na Bastilha.
} 
Apesar de notoriamente libertina, no contexto da Revolução Francesa a escrita de Sade ganha contornos certamente mais audaciosos. A Filosofía na alcova causou escândalo à época, contando com um público bastante significativo quando comparado a outras obras como Lolotte et Fanfan, do romancista sentimental Ducray-Duminil. Sade significou um perigo para os revolucionários franceses, não por rejeitar os ideais de liberdade, mas por levar esse conceito ao extremo, proclamando o triunfo do vício sobre a virtude, desencaminhando a liberdade, a igualdade e a fraternidade. Que liberdade era essa? Ora, aquela fundada na ideia da busca pelo prazer a qualquer custo, sem freios ou amarras. Ou seja, sem consideração à lei, a convenções e ao desejo alheio. Filosoficamente, Sade acreditava que a natureza e a razão apenas deviam servir ao egoísmo absoluto.

A Filosofia na alcova não é apenas um clássico da literatura erótica. É o próprio manual dos libertinos. Tem como protagonista a jovem Eugénie (15 anos), «filha de um certo Mistival, um dos mais ricos arrecadadores da capital» (Sade, 2015: 21), descrita como uma virgem de brancura deslumbrante, de olhos negros de ébano e de longos cabelos castanhos. Seu irmão incestuoso (Cavaleiro de Mirvel) entregou-lhe à Madame de Saint-Ange, encarregada da «educação» erótica da jovem. A formação de Eugénie consistirá basicamente de discussões filosóficas e práticas sexuais, que objetivavam libertá-la das virtudes quiméricas e religiosas. Ou, para ser mais direto, a educação da jovem baseia-se em «un peu de parole, un peu de foutre», tudo em perfeita sintonia (Garbouj, 1980: 219). Durante os momentos de «pausa», entre a prática da sodomia ou outras penetrações, os protagonistas abordam diversos temas: Deus, política, castidade, crime, incesto, liberdade, casamento, pudor, ateísmo, laicidade do Estado, prostituição, assassinato, moralidade, etc. Esses temas buscam afastar a porosa fronteira entre realidade e imaginação. Eles permitem que o leitor transponha o limite da imaginação, dando azo às mais diversas fantasias, como bem o mostrou Michel Foucault (2016).

Seria, portanto, mais conveniente falar aqui em «deseducação», na qual o corpo da jovem se configura em espécie de laboratório do libertino. Corpo-laboratório que recusa a aceitação passiva da vida, nega a vontade divina, debocha das prescrições cristãs e recusa a obediência cega. Eis a importância literária que tem Eugénie: ela representa a negação de tudo que sustentava a ordem do Antigo Regime. A crítica à religião e seus dispositivos direção de consciência, confissão, penitência - é implicitamente apresentada. A tarefa é enorme. Requer ajuda. Para auxiliar Saint-Ange, Sade introduz na história um amigo do irmão de Eugénie, o senhor Dolmancé (ateísta e sodomita ativo/passivo), célebre devasso de idade de 36 anos e tido como «celerado e cruel» (Sade, 2015: 16), além do jardineiro 
Agostinho9 ${ }^{9}$, cujo membro tinha «treze polegadas de comprimento por oito e meia de circunferência» (Sade, 2015: 94).

Eugénie precisava reaprender a ver seu mundo. Deveria estar aberta a novos olhares. Carecia, enfim, de uma nova identidade: parece que é somente sob esse viés que se pode fazer uma análise mais precisa de A Filosofia na alcova, uma vez que, em quase toda a extensão do livro, costumes e religião são desprezados e reduzidos à insignificância, constituindo bases falsas nas quais as mulheres colocavam suas esperanças. Em Sade, Deus não existe e a virtude não passa de uma fantasia.

A obra se destaca por alçar o privado a um lugar especial, uma vez que ele é necessário para os prazeres bizarros e jogos sexuais mais cruéis, apresentando-se sob a forma do Boudoir. O domínio privado por excelência em Sade são os espaços fechados. Eles representam a barreira contra o «caos» do exterior. Cavernas, castelos isolados do mundo, criptas, passagens subterrâneas e grutas figuram entre os locais preferidos do autor de Justine. É claro que se deve matizar essa ideia de que

\footnotetext{
${ }^{9} \mathrm{O}$ costume determinava que a mulher escolhia a criadagem. No século XVIII era a mulher quem dirigia os trabalhos da casa, tendo com os subalternos sentimentos de familiaridade que beiravam à cumplicidade a exemplo do que ocorria na residência de madame de Pollastron (1749-1793). Era a mulher, ainda, a responsável pela economia doméstica. A economia externa, mercantil pertence a seu esposo: nas obras literárias desse período, dificilmente se vê a mulher concluindo contratos em feiras, manipulando o crédito nem emprestando dinheiro ao seu marido.
}

o interior é melhor que o exterior. Os indícios sugerem, na verdade, que o interior é hipervalorizado, mas apenas sob a forma de encarceramento, reclusão, isolamento.

Por que tamanho reconhecimento dos espaços fechados? Talvez para que o leitor se lembrasse constantemente de que o autor da obra vivera grande parte de sua vida encarcerado. Mas, acima de tudo, porque o espaço fechado é mais propício aos prazeres libertinos que são, quase sempre, incompreendidos pela maioria. No conjunto, paradoxalmente locais vedados constituem um refúgio ou uma espécie de retiro. É sinônimo de fuga. Espaço e liberdade possuem, dentro dessa ordem, uma relação complexa e estreita ainda a ser melhor estudada pelos estudiosos da Literatura. É somente nos espaços fechados que as vítimas dos libertinos estão à mercê de tudo: tornam-se impotentes e frágeis diante de seus senhores. O cenário em A Filosofia na alcova deve ser estudado levando-se em consideração essas características: o boudoir é uma ilha no meio de um oceano. Representa, antes de tudo, o isolamento moral do libertino.

No título original, faz-se uso dessa palavra, boudoir. No português é certamente difícil traduzi-la. Em geral, trata-se de uma espécie de cômodo em que as damas e aristocratas francesas do século XVIII recebiam os convi- 
dados mais íntimos ${ }^{10}$. Local sigiloso, o boudoir representava, acima de tudo, o recôndito privilegiado da mulher: era ali que ela se despia, física e simbolicamente. Nesse contexto, o toque epidérmico assumia importância capital: era nesse microcosmo que as criadas amarravam os laços dos espartilhos, prendiam os botões, atavam laços, deslizavam, enfim, suas mãos pelo corpo das senhoras. Local de intimidade, de descanso e dos cuidados do corpo, o boudoir encerrava o sexo entre suas paredes. A sua aparência relaciona-se às mudanças nas relações de gênero observadas durante o século XVIII. Era uma maneira de dizer aos homens que as mulheres possuíam um espaço próprio, refúgio de atos íntimos. Não é à toa que este local evocasse a estimulação do desejo masculino. Seria isto resultado de seu caráter privativo? Se assim o for, talvez isso explique por que Sade escolheu o boudoir como pano de fundo da história.

Para Eliane Moraes, há no boudoir de Saint-Ange uma clara economia dos objetos: os detalhes que compõem esse ambiente são pobremente descritos pelo autor. Lugar de informalidade e descontração, o pequeno aposento apresenta-se como o oposto da Câmara de Assembleias do Castelo de Silling. Na verdade, afirma a autora, o boudoir constitui apenas

\footnotetext{
10 Desde 1787, a palavra Boudoir aparece ligada a conteúdos eróticos, como se pode ver no Manuel des boudoirs ou Essais érotiques sur les demoiselles d'Athènes, escritos por Mercier de Compiègne.
}

uma das muitas palavras que os homens do século XVIII criaram para «dar conta desse tema fundamental da sociedade Setecentista, a privacidade» (Moraes, 2015: 223). Isso é revelado pelo estudo da arquitetura.

Michele Perrot foi uma das historiadoras que mais se dedicou ao tema. Investigando os interiores, sejam burgueses, aristocráticos ou operários, ela mostrou que a vida privada no Ocidente sempre buscou encarcerar-se por muros. A quarto é o lugar de existência do sujeito e possui aspectos multifacetados: ponto de encontro, templo das coisas íntimas, recinto de descanso e, ainda, ambiente de memória (Perrot, 2011: 16-17). Nesse sentido, questiona-se: o que representa o quarto? Não se trata de uma simples «caixa» composta de quatro paredes e janelas. Metaforicamente, é a figura triunfante do imaginário romântico. Nesse sentido, várias são as privacidades que o século xvIII produziu, o que ajuda a explicar a dificuldade em traduzir a palavra Boudoir para outras línguas.

Ainda assim, é importante destacar que Sade constitui um expressivo formulador desse sentimento de intimidade que a Europa via nascer. A privacidade moderna surgiu a partir da indiferença em relação ao social. A nobreza e a burguesia, as únicas que efetivamente mais saíram ganhando com a Revolução, clamavam por zonas de segredo. É razoável supor que houvesse uma recusa pelos ajuntamentos sociais. A massa é perigosa se unida em torno 
de algo comum. 0 povo revoltado faz tremer as bases de qualquer sistema político, como o demonstra o Terror Jacobino. Essa distância do social era, portanto, uma característica da época. A este respeito, aliás, Philippe Ariès demonstrou como as famílias nobres e burguesas procuraram, ao longo do século XVIII, manter distância da sociedade, confinando-se em espaços limitados.

Está-se diante de uma reação face às ruas revolucionárias da Paris? A questão poderia delongar muitas páginas. Por ora, basta ter em mente que Versalhes viu surgir esse sentimento de isolamento com Madame de Pompadour e, mais tarde, com Maria Antonieta; esta última, avessa aos ritos palacianos e às fofocas aristocráticas, instalava-se no Petit Trianon quando queria receber seus amigos sem formalidades. Ainda em Paris, no Museu Jacquemart-André, também é possível observar nichos caracterizados por suntuosa decoração têxtil, paredes decoradas por obras de arte italianas, objetos de coleção e o famoso boudoir des époux, em que se percebe que o processo de isolamento se instalara na família francesa (aristocrática e burguesa) no século XVIII.

Como a análise histórica não deve perder de vista as questões literárias, atente-se a estas últimas. Em A Filosofia na alcova, à medida que a história se desenvolve no boudoir, o erótico aparece. Não se trata de uma simples coincidência. As duas questões - espaço e eroticidade - decorrem de uma situação geral, na qual os personagens vivenciam sua própria existência. É lá que os relatos das paixões ganham terreno. É no espaço fechado da intimidade que as relações de poder se opacificam, que as instituições religiosas com seus dogmas perdem sua influência, que os tabus são questionados e, por fim, que a liberdade do sujeito se articula com suas práticas. A prática definirá, portanto, uma espécie de modus vivendi privado, caracterizado pelo total desapego às regras sociais, culturais e religiosas. O essencial não é, pois, educar Eugénie teoricamente, mas permitir a fundação de uma vivência que se expresse por práticas. Em Sade, não basta falar, ensinar, dizer. É preciso praticar o que se diz.

Acerca da relação entre teoria e prática em A Filosofia na alcova, afirma Eliane Moraes:

\footnotetext{
O que se aprende nessa escola é simultaneamente um conhecimento e uma forma de prazer. Scientia sexualis e a ars erotica reúnem-se em Sade: não há saber que não seja prazeroso, e essa marca da pedagogia libertina predispõe o viajante aprendiz, sempre, a uma nova lição. (2015: 59)
}

Sade coloca no cerne dessa literatura a ideia de que a educação da garota deve obedecer a métodos próprios, a partir de técnicas sexuais reformadoras que têm como objetivo final a transformação do indivíduo. Daí a importância do Boudoir: é nesse lugar deserdado (como outrora os «desertos» para onde os monges 
partiam em busca de refúgio do mundo) que os personagens de Sade partem em busca de uma proteção. É o lugar-esconderijo, o espaço-obscuro, o terreno-subterrâneo. O Boudoir simboliza, acima de tudo, o local dos encontros, dos prazeres inconfessáveis, dos gozos privados. Locus voluptatis, tal como os jardins amorosos de $O$ vermelho e o negro, de Sthendal.

Convém se questionar: como é representada a figura feminina em A Filosofia na alcova? O que os discursos de Sade explicitam?

Em primeiro lugar, que essa escrita é difícil de caracterizar devido a sua imprecisão e ambiguidade no que se refere à representação da mulher. Michel Delon ressaltou que esse discurso era misógino e feminista ao mesmo tempo (1979: 419). Eis uma característica anfibológica da obra sadiana, e que coloca as personagens femininas como vítimas (dominadas, vencidas, subjugadas), cujo papel principal reside na disposição «em se deixarem acorrentar pelos homens, tendo como única identidade a de objetos sexuais» (Hunt, 2009: 44). Apesar de aparentemente irrelevante, essa questão interessa aqui ao menos em dois aspectos: trata-se de interrogar as figuras femininas e observar as regras de composição dos personagens ao longo da obra.

Tal problemática não é novidade nos estudos literários. Ela já foi esboçada, ao menos em parte, por Bénédict Prot (2013), no que se refere ao teatro sadiano. Mas ela reapre- sentou-se em nossa mente ao analisar A Filosofía na alcova, parecendo inevitável voltar a indagar o texto literário, tomando-o como fonte histórica. Todavia, para melhor delimitar possíveis resultados, talvez seja interessante partir de uma análise que privilegie o sistema de representações, de signos e de traços que constituem a figura da mulher especificamente nesse livro.

Aos olhos de Sade, que abandona a ideia de «agrilhoar» a sexualidade feminina, a liberdade corporal deve ser característica primeira da mulher. «Teu corpo só a ti pertence; só tu no mundo tens o direito de gozar dele e fazer gozar a quem bem quiseres» diz Saint-Ange à Eugénie (Sade, 2015: 50). Saint-Ange também aborda a questão desse corpo livre de freios ao desdenhar do matrimônio:

Há coisa mais ridícula do que ver uma jovem de quinze ou dezesseis anos ardendo de desejos que é obrigada a vencer, esperar, em tormentos piores que os do inferno, que agrade a seus pais, após tornarem sua juventude infeliz, sacrificar também sua maturidade imolando-a à sua pérfida ambição, associando-a, a contragosto, a um esposo que não vale a pena ser amado ou que tem tudo para ser odiado? [...] O destino da mulher é ser como a loba e a cadela: pertencer a todos os que a desejarem. É visivelmente ultrajar a destinação que a natureza impôs às mulheres, atando-as pelo laço absurdo de um himeneu solitário. (Sade, 2015: 48) 
Entra em cena o casamento ${ }^{11}$, objeto de desconfiança por parte de Sade. Nesse tipo de contrato, a mulher sempre perdia: o poder paterno apenas transferia-se ao poder marital. Em nome da natureza, o Código Civil Napoleônico (1803-1804) estabeleceu a autoridade absoluta do marido no lar. Sob o casamento, jugo pesado, diversos direitos eram negados à mulher: não podia ser testemunha em tribunais, nem tutora, nem dispor de seus bens na comunidade, e ainda thes negavam o direito de dispor de seu próprio salário, o que subsistiu até 1907.

Convém lembrar que a difusão da escrita sadiana ocorreu em meio a um debate acerca dos direitos das mulheres: Olympe de Gouges, Théroigne de Méricourt, Etta Palm e Claire Lacombe, dentre outras, aproveitaram o clima de agitação revolucionária do século XVIII para reclamar a igualdade formal entre homens e mulheres. 0 foco de Sade é claro: numa época em que a mulher era vista como ser inferior ao homem, a escrita sadiana, na contramão de seu tempo, busca assegurar-lhe a liberdade, incentivando-a a pisotear os possíveis grilhões que a escravizavam - religião, costumes,

\footnotetext{
11 Madame de Maintenon alertava as moças da ilusão dos confortos do casamento, uma vez que o papel de esposa representa apenas mais um acréscimo de deveres e limitações. A mulher casada, afirmava, sacrifica os momentos de lazer e de descanso em favor da sua família que deverá ocupar a primazia em sua vida. É da autora a frase: «eu seria enfadonha se vos dissesse o que é o casamento» (1885). Acerca das ilusões do casamento apregoadas por Maintenon, convém verificar o estudo de Christine Mongenot (2007).
}

tradições, etc. Trata-se de entender que a mulher não devia reconhecer nenhuma soberania acima dela. Ela não está amarrada a ninguém, nem mesmo a sua família.

Aliás, a mãe, em Sade, não está isenta das atividades de que se ocupam os libertinos: são vítimas privilegiadas, uma vez que muitos libertinos iniciam sua vida criminal com a própria mãe. A figura da mãe de Eugénie é representada em A Filosofia na alcova como controladora ${ }^{12}$, impertinente, supersticiosa, beata, rabugenta, hipócrita, carola ${ }^{13}$, falsa caridosa ${ }^{14}$, imbecil ${ }^{15}$ e abominável.

Conversar, fofocar, brigar: três verbos que constituem o estilo de «vida feminino». Elas aparecem no texto como tendo o poder de formar a opinião pública. Sua reputação é caricatural: as mulheres falam e espalham os mexericos. São responsáveis por desencadear o escândalo na sociedade, demonstrando que possuem armas poderosas. Basta testemunhar

\footnotetext{
12 «Minha mãe opunha-se inteiramente a esta deliciosa partida, dizendo não ser conveniente a uma jovem de minha idade sair sozinha» (Sade, 2015: 23).

13 «Se existe mãe no mundo que deva ser odiada, é seguramente a tua! Impertinente, supersticiosa, beata, rabugenta...e de uma hipocrisia revoltante; aposto que essa falsa carola jamais deu um passo em falso na vida» (Sade, 2015: 36).

14 «Cara amiga, meu pai pensa exatamente como o senhor Dolmancé: nunca fez uma boa ação na vida. Não cessa de censurar minha mãe pelas somas gastas com todas essas práticas. Ela pertence à Sociedade Maternal, à Sociedade Filantrópica, e não sei de que associação mais ela participa» (Sade, 2015: 45).

15 «despreza os conselhos vãos de uma mãe imbecil, a quem, legitimamente, só deves ódio e desprezo» (Sade, 2015: 49).
} 
uma falta grave para que ela acabe com uma reputação, como se observará em Stendhal: em $O$ vermelho e o negro, Elisa (empregada que se apaixonara por Julien Sorel) denuncia a patroa (a Sra. do Rênal), espalhando para toda a cidade de Verrières que Sorel e a Sra. do Rênal eram amantes. Este caráter vingativo se apresenta também em Sade. Saint-Ange e Dolmance vilipendiam tanto a figura materna que Eugénie, tomada pelo ódio que sente por sua mãe e pelo ânimo dos «ensinamentos», arquiteta ao final do livro a morte de sua própria progenitora.

DOLMANCÉ - Sede franca, Eugénie, nunca desejastes a morte de ninguém?

EUGÉNIE - Oh! Sim, sim, tenho diariamente sob os olhos uma abominável criatura que há muito tempo gostaria de ver no túmulo.

SAINT-ANGE - Aposto que sei quem é!

EUGÉNIE - De quem desconfias?

SAINT-ANGE - De tua mãe.

EUGÉNIE - Ah, deixa-me esconder meu rubor em teu seio!

DOLMANCÉ - Voluptuosa criatura! Também quero cobrir-te de carícias; é o prêmio da energia de teu coração e de tua deliciosa cabeça. (Sade, 2015: 68)

O assassinato de Madame de Mistival, mãe de Eugénie, expressa uma crítica radical às mulheres da sociedade da época. Sodomizada, flagelada e penetrada pelo criado que a contamina com uma doença, a senhora de Mistival tem seus genitais costurados pela própria filha, com o objetivo de garantir-lhe uma morte lenta. A maternidade, considerada sacerdócio, em Sade é enxotada para o reino do rebaixamento. Na verdade, a mãe de Eugénie representava uma expressiva parcela das mulheres francesas que se dedicavam exclusivamente ao lar e aos filhos, pondo de lado o «caminho da natureza». Não passavam de seres perdidos em máscaras sociais. Eugénie, por outro lado, representava a mulher liberta de «obrigações sociais». Modelo de mãe, modelo de mulher. Era o que se exigia do sexo feminino naquela época. Sade dirá que esse papel é ridículo. Renunciar às virtudes, rejeitar os preconceitos, afastar-se da religião, entregar-se aos desejos e aos impulsos naturais, além de possuir uma liberdade em relação ao uso do corpo contribuem para a difusão de um código singular ou, o que é mais interessante, para o desenvolvimento de uma caracterização do ideal de mulher na obra sadiana.Seus escritos tentam contribuir para a consolidação desse processo. Processo que deve embasar a atividade cotidiana da mulher e se manifestar prioritariamente por atos. Nessa perspectiva, a feminilidade devia se identificar com o prazer sexual - noção essencial - e com o uso liberal do corpo.

A ideia de Sade é atestar que o prazer deve ser o objetivo primeiro da vida de uma mulher. Defendia o vigor do prazer sexual sem limites. A recatada, a tímida, a pudica, a virtuosa, a submissa e a casta são, mais do que nunca, objetos de desprezo e repugnância. Para compreender cabalmente o que representa esse 
modelo é indispensável retornar mais precisamente ao que lhe dá sustentação: a própria obra literária. Em A Filosofía na alcova, Sade inculca no leitor a ideia de que as noções de feminilidade se encontravam ancoradas no universo dos ocidentais bem antes do século XVIII. Para apreender corretamente o que acontece na ordem do imaginário social deve-se tomar em consideração a importância do fenômeno religioso. 0 problema era que a religião incutia valores nas mulheres e perverti-as como falsos princípios morais, educando-as para o pudor e a decência. 0 teísmo, como sói acontecer, é constantemente criticado como doutrina indigna e ridícula, que merece apenas o desprezo das mulheres.

\section{Considerações finais}

A construção das personagens femininas em A Filosofia na alcova ajuda a entender as diferentes representações da sexualidade libertina que, sendo o oposto do ideal heteronormativo, não foram compreendidas pela sociedade francesa do século XVIII. Sade defendia a ideia de que a mulher deveria, em matéria sexual, ser tão livre como o homem. É verdade que nem todos concordam com essa interpretação. Kate Millet (2000) e Jane Gallop (2005) afirmam, por exemplo, que as representações de Sade no que se refere ao sexo feminino reproduzem um sistema de valores baseado na dominação masculina sobre as mulheres. Isso é válido para grande parte de suas obras. Todavia, A Filosofía na alcova põe em jogo uma reflexão que permite estabelecer algumas relações com as reivindicações dos direitos das mulheres na atualidade.

Seguindo Stéphanie Genand (2015), muitos críticos estão de acordo com a ideia de que a construção da feminilidade em Sade não nasce de um pensamento essencialista: Eugénie, ao longo de suas aulas, expõe e defende a teoria da apatia libertina e critica a educação moral cristã que tanto agrilhoava as mulheres. Em A Filosofia na alcova o objetivo manifesto de Sade é descrever questões relativas à sexualidade da mulher: seu desejo era que a mulher deveria fazer um trabalho interior para adequar seu corpo aos prazeres libertinos. A partir disso, Sade feriu a sociedade da época no que ela tinha de mais basilar - as relações entre os sexos -, defendendo a criação de uma nova organização social, fundada na transgressão de princípios caros ao Ocidente cristão. Este propósito, parece, só poderia ser produzido pela mescla de todas as classes ou pela inversão simultânea de todos os princípios.

O texto de Sade permite entender a crítica de George Bataille no que tange ao século «pobre» da Literatura Francesa. O livro é singular, talvez o mais extraordinário desse tipo dentro do conjunto de histórias libertinas que inundavam as casas dos burgueses de Paris no século XVIII. Foi preciso a guerra, o desespero e a violência para que fossem estabelecidas as bases de uma escrita que, lentamente e ao sabor do ritmo das transformações sociais da 
época, atentava contra as históricas relações estabelecidas entre os sexos ao longo de anos de História.

\section{Bibliografia}

Ariès, P. (1978). História social da criança e da família. (Trad. D. Flaksman). Zahar. Rio de Janeiro;

Badinter, E. (org.) (1991). Palavras de homens (1790-1793). (Trad. M.H.F. Martins). Editora Nova Fronteira. Rio de Janeiro;

Battaile, G. (2015). A Literatura e o mal. (Trad. F. Scheibe). Autêntica Editora. Belo Horizonte;

Belaval, Y. (1976). Préface. Em: Sade, La philosophie dans le boudoir: Ou les instituers immoraux. Gallimard. Paris;

Borges, L.A.C. (2015). A revolução da palavra libertina. Em: Marquês de Sade, A Filosofia na alcova. (Trad. C. Borges). Iluminuras. São Paulo;

Brochier,J.J. (1968). La circularité de l'espace. Le Marquis de Sade: Colloque d'Aix-en-Provence sur le Marquis de Sade. Armand Colin. Paris;

Castan, N. (2009). O público e o particular. Em: R. Chartier (org.), História da vida privada. (Trad. $\mathrm{H}$. Feist). Companhia das Letras. São Paulo. Vol. 3;

Chartier, R. (2009). As práticas de escrita. Em: R. Chartier (org.), História da vida privada. (Trad. $\mathrm{H}$. Feist). Companhia das Letras. São Paulo. Vol. 3;

Darnton, R. (1987). Boêmia literária e revolução. O submundo das letras no Antigo Regime. Companhia das Letras. São Paulo;

Delon, M. (1979). Dix ans d'études sadiennes. Dix-Huitème Siècle. 11: 393-426;

Delumeau, J. (2004). A civilização do Renascimento. Edições 70. Lisboa;

Foucault, M. (2016). Conferência sobre Sade. Em: M. Foucault, A grande estrangeira: Sobre literatura. (Trad. F. Scheibe). Autêntica Editora. Belo Horizonte;

Gallop, J. (2005). The liberated woman. Narrative. 13: 89-104;

Gallop, J. (2013). Sade, les mères, et les autres femmes. Itinéraires. 2: 187-202;
Garbouj, B. (1980). L'infraction didactique. Notes sur La Philosophie dans le boudoir. Dix-Huitième Siècle. 12: 219-229;

Genand, S. (2015). Le libertinage existe-t-il au féminin? Le cas Justine dans l'oeuvre de Sade. Revue de la BNF. 50: 14-19;

Le Goff, J. (1991). Pour un autre Moyen Âge. Gallimard. Paris;

Goulemot, J.M. (2009). As práticas literárias ou a publicidade do privado. Em: R. Chartier (org.), História da vida privada. (Trad. H. Feist). Companhia das Letras. São Paulo. Vol. 3;

Hobsbawm, E. (2008). A era das revoluções: Europa 1789-1848. Paz e Terra. Rio de Janeiro;

Hunt, L. (2009). Revolução francesa e vida prin vada. Em: M. Perrot (org.), História da vida privada. (Trad. D. Bottmann e B. Joffily). Companhia das Letras. São Paulo. Vol. 4;

Hunt, L. (2012). A invenção dos direitos humanos: Uma história. A Página. Curitiba;

Lisboa, J.L. e Miranda, T.C.P.R. (2010) A cultura escrita nos espaços privados. Em: J. Mattoso (ed.), História da vida privada em Portugal. Círculo de Leitores. Lisboa. Vol. 2;

Maintenon, Madame de (1885). Sur l'éducation. Hachette. Paris;

Millet, K. (2000). Sexual politics. University of ILlinois Press. Chicago;

Molière (2011). L'école des femmes. La critique de Lécole des femmes. Apresentação de Bénédicte Louvat-Molozay. Flammarion. Paris;

Mongenot, C. (2007). De $\mathrm{M}^{\mathrm{me}}$ de Maintenon aux auteurs de théâtres d'éducation: Avatars ou mutations de la «conversation pédagogique». Em: Femmes éducatrices au siècle des Lumières: Discours et pratiques. Presses Universitaires de Rennes. Rennes;

Moraes, E.R. (2015). Sade: A felicidade libertina. (2. ${ }^{a}$ ed.). Iluminuras. São Paulo;

Nolhac, P. (1913). Le trianon de Marie-Antoinette. Calmann-Lévy. Paris; 
Perrot, M. (2008). Minha história das mulheres. (Trad. A.M.S. Corrêa). Contexto. São Paulo;

Perrot, M. (2011). História dos quartos. (Trad. A. Brant). Paz e Terra. São Paulo;

Plumd-Dhindsa, P. (1998). From Royal Bed to Boudoir: The Dissolution of the Space of Appearance Told Through the History of the French Salon. Tese de Mestrado em Arquitetura. McGill University. Monréal; 119 pp.;

Prot, B. (2013). Les femmes et le comique dans le théâtre du Marquis de Sade. Itinéraires. 2: 153-165;
Ranum, O. (2009). Os refúgios da intimidade. Em: R. Chartier (org.), História da vida privada. (Trad. H. Feist). Companhia das Letras. São Paulo. Vol. 3;

Sade, Marquês de (2015). A Filosofía na alcova. (Trad. posfácio e notas C. Borges). Iluminuras. São Paulo;

Verney, L.A. (1953). Verdadeiro método de estudar. Ed. org. por António Salgado Júnior. Sá da Costa. Lisboa. Vol. 5. 